\title{
Front Matter: Volume 11116
}

, "Front Matter: Volume 11116," Proc. SPIE 11116, Astronomical Optics:

Design, Manufacture, and Test of Space and Ground Systems II, 1111601 (11 October 2019); doi: 10.1117/12.2552795

EDIE Event: SPIE Optical Engineering + Applications, 2019, San Diego, California, SPIE. United States 


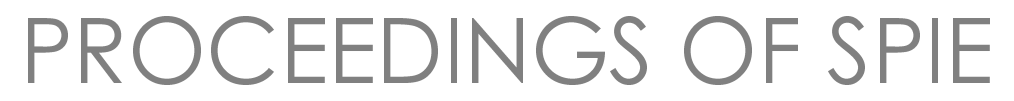

\section{Astronomical Optics: Design, Manufacture, and Test of Space and Ground Systems II}

Tony B. Hull

Dae Wook Kim

Pascal Hallibert

Editors

12-15 August 2019

San Diego, California, United States

Sponsored and Published by

SPIE

Volume 11116 
The papers in this volume were part of the technical conference cited on the cover and title page. Papers were selected and subject to review by the editors and conference program committee. Some conference presentations may not be available for publication. Additional papers and presentation recordings may be available online in the SPIE Digital Library at SPIEDigitallibrary.org.

The papers reflect the work and thoughts of the authors and are published herein as submitted. The publisher is not responsible for the validity of the information or for any outcomes resulting from reliance thereon.

Please use the following format to cite material from these proceedings:

Author(s), "Title of Paper," in Astronomical Optics: Design, Manufacture, and Test of Space and Ground Systems II, edited by Tony B. Hull, Dae Wook Kim, Pascal Hallibert, Proceedings of SPIE Vol. 11116 (SPIE, Bellingham, WA, 2019) Seven-digit Article CID Number.

ISSN: 0277-786X

ISSN: 1996-756X (electronic)

ISBN: 9781510629257

ISBN: 9781510629264 (electronic)

Published by

SPIE

P.O. Box 10, Bellingham, Washington 98227-0010 USA

Telephone +1 3606763290 (Pacific Time) · Fax +13606471445

SPIE.org

Copyright @ 2019, Society of Photo-Optical Instrumentation Engineers.

Copying of material in this book for internal or personal use, or for the internal or personal use of specific clients, beyond the fair use provisions granted by the U.S. Copyright Law is authorized by SPIE subject to payment of copying fees. The Transactional Reporting Service base fee for this volume is $\$ 21.00$ per article (or portion thereof), which should be paid directly to the Copyright Clearance Center (CCC), 222 Rosewood Drive, Danvers, MA 01923. Payment may also be made electronically through CCC Online at copyright.com. Other copying for republication, resale, advertising or promotion, or any form of systematic or multiple reproduction of any material in this book is prohibited except with permission in writing from the publisher. The CCC fee code is $0277-$ $786 \times / 19 / \$ 21.00$.

Printed in the United States of America by Curran Associates, Inc., under license from SPIE.

Publication of record for individual papers is online in the SPIE Digital Library.

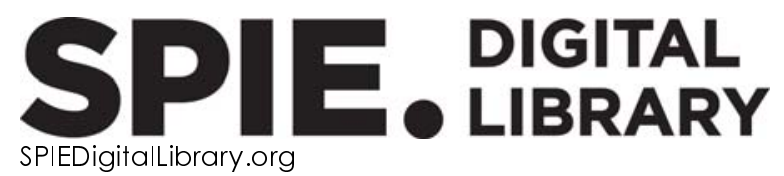

Paper Numbering: Proceedings of SPIE follow an e-First publication model. A unique citation identifier (CID) number is assigned to each article at the time of publication. Utilization of CIDs allows articles to be fully citable as soon as they are published online, and connects the same identifier to all online and print versions of the publication. SPIE uses a seven-digit CID article numbering system structured as follows:

- The first five digits correspond to the SPIE volume number.

- The last two digits indicate publication order within the volume using a Base 36 numbering system employing both numerals and letters. These two-number sets start with 00, 01, 02, 03, 04, 05, 06, 07, 08, 09, 0A, OB ... 0Z, followed by 10-1Z, 20-2Z, etc. The CID Number appears on each page of the manuscript. 


\title{
Contents
}

\author{
vii Authors \\ xi Conference Committee
}

Session 1 ADVANCED TELESCOPES AND INSTRUMENTS I

1111602 Twenty years of Chandra operations: telescope thermal performance and application of lessons learned to the Lynx mission [1 $11116-1$ - 1 ]

1111604 Technology development roadmap for Habitable-zone exoplanet observatory (HabEx) baseline 4-m primary mirror [1 $11116-3$ - 3 ]

1111605 CHEOPS: the characterizing exoplanets satellite ready for launch [1 $11116-4]$

1111606 Modular plug-in extension enabling cross-dispersed spectroscopy for Large Binocular Telescope [1 $11116-5]$

1111607 Challenges and benefits to achieving sub-millikelvin thermal control stability on large space observatories [1 $111116-6]$

Session 2 ADVANCED TELESCOPES AND INSTRUMENTS II

$1111608 \quad$ Nautilus Observatory: a space telescope array based on very large aperture ultralight diffractive optical elements [1 $11116-7]$

1111609 The upgraded camera for the prototype Schwarzschild-Couder Telescope of the Cherenkov Telescope Array [1 $11116-8]$

$111160 \mathrm{~A}$ Scale model of a dual dispersion primary objective grating telescope [1 $1116-9]$

$11116 \mathrm{OB}$ Design, manufacture, and verification of bandpass filter for multispectral remote sensing in micro-satellite [1 $11116-10]$

\section{Session $3 \quad$ ADVANCED TELESCOPES AND INSTRUMENTS III}

$111160 \mathrm{D} \quad$ Optical design of a modular segmented space telescope [11116-12]

11116 OE Optical modeling and testing of the Deformable Mirror Demonstration Mission (DeMi) CubeSat payload [1 $11116-13]$ 
11116 OF Innovative compact coronagraph approach for Balloon-borne Investigation of Temperature and Speed of Electrons in the corona (BITSE) [1 $111116-14]$

1111606 Design of near-infrared sky brightness monitor for measurements in Antarctica [1 $1116-15]$

111160 Ol An in-flight calibration assembly for the earth observation instrument Sentinel-4 UVN [11116-17]

Session $4 \quad$ OPTICAL ENGINEERING PLENARY SESSION

11116 0J Making mirrors for giant telescopes (Plenary Paper) [1 $11116-202]$

Session 5 COATINGS AND MATERIALS I

$111160 \mathrm{~N}$ Characterization techniques and qualification tests of glass and optical coatings for space applications [1 $111116-20]$

$1111600 \quad$ Using ellipsometry and $x$-ray photoelectron spectroscopy for real-time monitoring of the oxidation of aluminum mirrors protected by ultrathin $\mathbf{M g F} \mathbf{F}_{2}$ layers [ $\left.1111116-21\right]$

11116 OP Extreme ultraviolet multilayers for solar physics applications: a brief review [1 $11116-22]$

$111160 Q \quad$ Mathematical analysis of hexagonal source arrangement for making uniform reflective aluminum coatings [1 $111116-23]$

Session 6 COATINGS AND MATERIALS II

$111160 R \quad$ Material selection of 3.5-meter segmented mirror for geostationary Earth observation satellite [1 $11116-26]$

11116 OS Radiation resistance of physical properties of low CTE ceramics and glass in high-dose-rate environments [1 $111116-24]$

11116 OT ZERODUR ${ }^{\circledR}$ substrates for application of high-temperature protected aluminum far-ultraviolet coatings [1 $11116-25]$

11116 OU Predictive thermal control (PTC) technology to enable thermally stable telescopes: first two year status [ $1111116-27]$

Session 7 OPTICAL TESTING AND VERIFICATION TECHNOLOGY

$111160 Y \quad$ Testing the near-infrared optical assembly of the space telescope Euclid [11116-31]

iv 
1111610 Technologies for large ultra-stable optical missions: current perspectives and developments at ESA [1 $111116-33]$

$1111611 \quad$ Active optics for space telescopes [11116-34]

OPTICAL MANUFACTURING AND FABRICATION TECHNOLOGY

1111613 Ion-beam figuring of x-ray mirrors [111116-37]

1111614 Development of a new normal-incidence cold-shaped mirror technology [11116-38]

Session $9 \quad$ ASTRONOMICAL INSTRUMENT COMPONENTS AND ASSEMBLIES

1111616 Additively manufactured mirrors for CubeSats [11116-41]

1111617 Lightweighting design optimisation for additively manufactured mirrors [11116-42]

1111618 Euclid warm testing of the near-infrared optical assembly using a unique combination of CGH interferometry and tactile precision measurements [1 1111 16-43]

$111161 \mathrm{~A}$ Installation, alignment method, and preliminary performance of the Thai National Telescope focal reducer [1 $11116-44]$

\section{POSTER SESSION}

11116 1B Development of high-efficiency reflective grating by holographic processing for UV exoplanet science [1 1111 l 6 -45]

$111161 \mathrm{C}$ The primary mirror of the ARIEL mission: study of thermal, figuring, and finishing treatments and optical characterization of Al 6061 samples mirrors [111116-46]

$111161 \mathrm{D}$ Accurate focusing technology for the coronal images [1 $11116-47]$

$111161 \mathrm{E} \quad$ Solar site testing at Mt. Wumingshan in Western China [1 $11116-48]$

$111161 \mathrm{~F} \quad$ arcusTrace: modular raytracing software for the Arcus x-ray spectrometer [11116-49]

$111161 G \quad$ EXOhSPEC collimator mechanical design [11116-50]

$111161 \mathrm{H} \quad$ Highly absorptive pupil mask fabricated with black silicon [11116-51] 
Proc. of SPIE Vol. $111161111601-6$

Downloaded From: https://www.spiedigitallibrary.org/conference-proceedings-of-spie on 26 Apr 2023 Terms of Use: https://www.spiedigitallibrary.org/terms-of-use 
Jiang, Peng, OG

Johnson, Brian I., 00

Jones, Hugh R. A., IG

Kaewsamoet, Pimon, $1 \mathrm{~A}$

Kameda, Shingo, 1B

Kaminski, Jennifer, OY, 18

Kamiya, T., OR, OS

Kang, Hyukmo, 06

Katterloher, Reinhard, OY

Kawinkij, Adithep, $1 \mathrm{G}$

Keithly, Dean, OD

Kim, Dae Wook, 06, 08

Knollenberg, Perry, 02

Kodama, Takanori, 1B

Kuchner, Marc, $1 \mathrm{H}$

Kuha, Teerawat, $1 \mathrm{G}$

Kuo, Leben, OB

Lamdan, Ariel, 06

Leckngam, Apichat, 1A, $1 G$

Lépine, Thierry, $1 \mathrm{~A}$

Lhospice, Esther, $1 \mathrm{G}$

Li, Xiao, 1D, 1E

Liang, Rongguang, 08

Linford, Matthew R., 00

Liotard, Arnaud, 11

Liu, YU, 1D, 1E

Lombini, Matteo, 1C

Louh, Nisrine, 11

Makino, Yoshitaka, 1B

Malaguti, Giuseppe, 1C

Marquet, B., 01

Martens, Brian, 07

Martin, H. M., OJ

Martin, William E., 1G

Mazy, E., 0 l

Membreno, Karen, 00

Merk, John, OE

Micela, Giuseppina, 1C

Milanova, Maria, 16, 17

Milster, Tom D., 08

Missaglia, Nadia, 1C

Mizutani, T., OR, OS

Mkrtichian, David, $1 \mathrm{G}$

Morgan, Rachel, OE

Morgan, Rhonda, 04

Morgante, Gianluca, 1C

Murakami, Go, 1B

Murata, Naotaka, 1B

Murphy, Thomas, OE

Narita, Norio, 1B

Nestler, Matthias, 13

Newberg, Heidi Jo, OA

Newmark, Jeffrey, OF

Ngernsujja, Surin, 1 A

Nistea, loana-Theodora, 16, 17

Okamoto, A., OR

Pace, Emanuele, $1 \mathrm{C}$

Palacios, R., 05

Panyaphirawat, Thirasak, $1 \mathrm{G}$

Paoletti, R., 09
Pareschi, Giovanni, 14

Parodi, Giancarlo, 14

Pearson, David, 16, 17

Pelizzo, Maria Guglielmina, 0N, OP

Penka, Daniela, 18

Petrone, Pete, $1 \mathrm{H}$

Plesseria, J. Y., OI

Poshyachinda, Saran, 1A, $1 G$

Prasit, Apirat, 1 A, 1G

Quijada, Manuel A., 0Q, OT

Rackham, Benjamin V., 08

Rando, N., 05

Rattanasoon, Somsawat, $1 \mathrm{G}$

Ratti, F., 05

Richardson, J. Gabriel, OQ, OT

Ridsdill-Smith, Matthew, IA

Rouillard, Hunter, OA

Safa, F., 05

Saha, Timo, $1 \mathrm{H}$

Santi, Giovanni, ON

Sasai, Hiroyuki, 1B

Sato, S., OR

Savransky, Dmitry, OD

Schneider, Glenn, 08

Schulze, Carsten, 13

Sechi, Gianfranco, 10

Shapiro, Jacob, OD

Sheikh, David A., OQ, OT

Shiri, Ron, $1 \mathrm{H}$

Shomper, Mary, 07

Sironi, Giorgia, 14

Smith, Randall K., $1 \mathrm{~F}$

Snell, Robert, 16, 17

Song, Qiwu, 1E

Song, Tengfei, 1D, $1 \mathrm{E}$

Soonthornthum, Boonrucksar, 1A, 1G

Soto, Gabriel, OD

Soummer, Remi, $1 \mathrm{H}$

Southworth, R., 05

Spinelli, Sebastiano, 1C

Stahl, H. Philip, 04, OU

Stein, Abigail, $\mathrm{OE}$

Suau, Aurélien, 11

Sucher, Damien, 11

Sun, Wenjuan, 16, 17

Swarm, Dustin K., $1 \mathrm{~F}$

Tang, Qi-Jie, OG

Terenzi, Luca, $1 \mathrm{C}$

Tessarolo, Enrico, $0 \mathrm{~N}$

Thompson, David, 06

Thummasorn, Griangsak, 1A, $1 G$

Todd, Stephen, 16, 17

Ueno, H., OR, OS

Valsecchi, Giuseppe, 14

Viard, Thierry, 11

Vogel, Conrad, 06

Voyer, Perry, 02, 07

Wahaus, Makayla, 0A

Wang, David, OB

Wang, Jian, $0 G$ 
Wang, Jingxing, 1D, 1E

Wang, Zhi-yue, OG

Wollack, Edward, $1 \mathrm{H}$

Xin, Yinzi, OE

Yasuda, S., OR

Zeuner, Michael, 13

Zhang, Guang-yu, OG

Zhang, Hong-fei, OG

Zhang, Jun, OG

Zhang, Qian, $0 \mathrm{G}$

Zhang, Shao-hua, OG

Zhang, Will, $1 \mathrm{H}$

Zhang, Xuefei, 1D, 1E

Zhang, Yi-hao, OG

Zhao, Mingyu, 1D, 1E

Zhu, Qing-feng, 0G

Zuppella, Paola, $1 C$

Proc. of SPIE Vol. 11116 1111601-9

Downloaded From: https://www.spiedigitallibrary.org/conference-proceedings-of-spie on 26 Apr 2023 Terms of Use: https://www.spiedigitallibrary.org/terms-of-use 
Proc. of SPIE Vol. 11116 1111601-10

Downloaded From: https://www.spiedigitallibrary.org/conference-proceedings-of-spie on 26 Apr 2023 Terms of Use: https://www.spiedigitallibrary.org/terms-of-use 


\section{Conference Committee}

Program Track Chair

Oswald H. Siegmund, University of California, Berkeley (United States)

Conference Chairs

Tony B. Hull, The University of New Mexico (United States)

Dae Wook Kim, College of Optical Sciences, The University of Arizona (United States)

Pascal Hallibert, European Space Research and Technology Center (Netherlands)

Conference Program Committee

Stephanie Behar-Lafenetre, Thales Alenia Space (France)

Raymond M. Bell Jr., Lockheed Martin Space Systems Company (United States)

Alain J. Corso, CNR-IFN Padova (Italy)

Laura E. Coyle, Ball Aerospace (United States)

James P. Hamilton, University of Wisconsin-Platteville (United States)

John M. Hill, Large Binocular Telescope Observatory (United States)

Frank Stefan Höller, Carl Zeiss AG (Germany)

Pengda Hong, Lehigh University (United States)

Joseph M. Howard, NASA Goddard Space Flight Center (United States)

Steven A. Macenka, Jet Propulsion Laboratory (United States)

Luca Maresi, European Space Research and Technology Center (Netherlands)

Maria Guglielmina Pelizzo, CNR-IFN Padova (Italy)

Narasimha S. Prasad, NASA Langley Research Center (United States)

Stuart B. Shaklan, Jet Propulsion Laboratory (United States)

Thomas Westerhoff, SCHOTT AG (Germany)

\section{Session Chairs}

1 Decadal Large Mission Concepts and Technology I: Joint Session with Conferences $11115,11116,11117$, and 11118

Allison A. Barto, Ball Aerospace (United States)

2 Decadal Large Mission Concepts and Technology II: Joint Session with Conferences $11115,11116,11117$, and 11118

Tony B. Hull, The University of New Mexico (United States)

Stuart B. Shaklan, Jet Propulsion Laboratory (United States) 
3 Advanced Telescopes and Instruments I

Tony B. Hull, The University of New Mexico (United States)

4 Advanced Telescopes and Instruments II

Lynn N. Allen, Harris Corporation (United States)

5 Advanced Telescopes and Instruments III

Pascal Hallibert, European Space Research and Technology Center (Netherlands)

6 Coatings and Materials I

David A. Sheikh, ZeCoat Corporation (United States)

7 Coatings and Materials II

James P. Hamilton, University of Wisconsin-Platteville (United States)

8 Optical Testing and Verification Technology

Dae Wook Kim, College of Optical Sciences, The University of Arizona (United States)

9 Ultra Stable Telescope Design, Control, and Systems

Stéphanie Behar-Lafenetre, Thales Alenia Space (France)

10 Optical Manufacturing and Fabrication Technology

Laura E. Coyle, Ball Aerospace (United States)

11 Astronomical Instrument Components and Assemblies

Pascal Hallibert, European Space Research and Technology Center (Netherlands) 